\title{
The Lac Cornu retrograded eclogites (Aiguilles Rouges massif, Western Alps, France): evidence of crustal origin and metasomatic alteration
}

\author{
JEAN-PAUL LIEGEOIS \& JEAN-CLAIR DUCHESNE
}
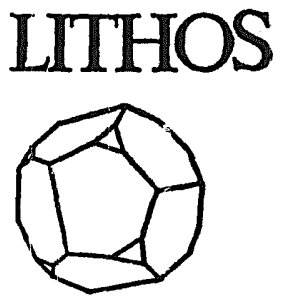

Liégeois, J. P. \& Duchesne, J. C. 1981: The Lac Cornu retrograded eclogites (Aiguilles Rouges massif, Western Alps, France): evidence of crustal origin and metasomatic alteration. Lithos 14, 35-48. Oslo. ISSN 0024-4937.

Metabasic rocks interbedded in amphibolite facies supracrustal gneisses outcrop around Lac Cornu in the Aiguilles Rouges massif (Western Alps). The cores of the thickest boudinaged lenses are made up of eclogitic amphibolites grading outwards into amphibolites. The common assemblage is unzone d garnet + symplectitic clinopyroxene + hornblende + plagioclase. In a slighily amphibolitized sample, minimum $P$ and $T$ conditions of equilibrium between garnet and omphacite inclusions are $780^{\circ} \mathrm{C}$ and 11 Kb. A polymetamorphic pre-Alpine evolution of the massif is thus domonstrated. Eclogitic amphibolites show variations in major element composition similar to the Skaergaard evolution in the $\mathrm{Al}_{2} \mathrm{O}_{3}-\mathrm{FeO}+$ $\mathrm{Fe}_{2} \mathrm{O}_{3}-\mathrm{MgO}$ triangle. Variation diagrams in which $\mathrm{Zr}$ is taken as differentiation index also irdicate magmatic trends for $\mathrm{Mn}, \mathrm{Ti}, \mathrm{P}, \mathrm{Ni}, \mathrm{Co}, \mathrm{Y}, \mathrm{V}$ and $\mathrm{Cr} . \mathrm{Ca}, \mathrm{K}, \mathrm{Na}, \mathrm{Sr}, \mathrm{Rt}$ and $\mathrm{Si}$ were mobile during the evolution of the rocks. The igneous trend can be described by a quantitative model of fractional crystallization in which a noritic assemblage separated in the initial stage. This provides evidence of crustal P,T conditions of differentiation for the original material and in situ evolution for the eclogites. A second group of anphibolites shows banded structure and transitional terms with the surrounding gneisses. A volcano-sedimentary origin is suggested though the process cannot be modelled. The rocks may result from conplex interactions of magmatic, metasomatic and sedimentary processes. It is concluded that Lac Cornu metabasites were originally contincntal the leiites, though severa? geochemical criteria tend to indicate an oceanic origin. This casts some doubt on the validity of these criteria, when applied to metamorphic rocks.

Jean-Paul Liégeois, Géologie, Pétrologie et Géochimie, Université de Liège, 4000 Sart Tilınan (Belgium). Present address: Centre Belge de Géochronologie, Musée Royal de l'Afrique Centrale, 1980 Tervuren (Belgium).

Jean-Clair Duchesne, Géologie, Pétrologie et Géochimie, L'niversité de Liège, 4000 Sart Tilınan (Belgium).
Eclogite relics in metamorphic terranes are interesting from several points of view. Under what pressure and temperature conditions were they transformed into eclogites? How did they behave during subsequent metamorphic episodes? Were high grade metamorphic processes isochemical? Is it possible to distinguish between para- and ortho-eclogites? If igneous in origin, do they provide any evidence of an evolution under crustal conditions (e.g. Bryhni et al. 1977; Krogh 1977) or do they come directly from the mantle, being emplaced tectonically in the upper crust (e.g. Lappin \& Smith 1978)? Can the original nature of the magma throw some light on the geodynamic process of magma generation?

The aim of the present paper is to show that the petrology and geochemistry of Lac Cornu eclogites can answer most of these questions.

\section{Geology}

The Aiguilles Rouges massif (Western Alps) is part of the autochthonous crystalline basement of the Alps. It has been mapped and described by Bellière $(1958,1980 \mathrm{a}, 1980 \mathrm{~b})$, who presunted a detailed petrographic account. The massif is, for the most part, made up of micaschists and gneisses, often migmatitic, of various compositions (pelitic to greywacke). Subordinate amounts of graphitic schists, calcite marbles, calc-silicate gneisses, amphibole-bearing schists and amphibolites are also observed.

The rocks belong on a regional scale to the almandine-amphibolite subfacies. The age of the metamorphism which induced this regional facies is not known, except that it is older than upper-Visean (Bellicre \& Streel 1980). The Alpine orogeny did rot produce any penetrative 


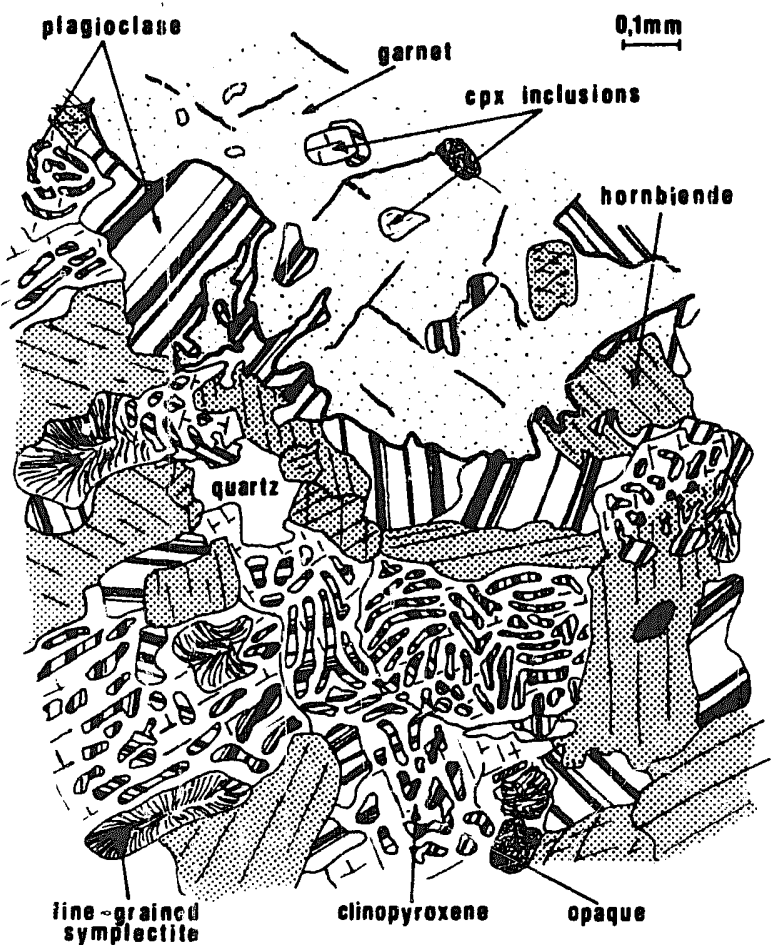

Fig. I. Schematic petrographic representation of the garnetclinopyroxene-plagioclase-hornblende association in the eclogite amphibolite (see text).

deformation. Its influence is restricted to shear or fracture zones with local retrogression to prehnite-pumpellyite facies conditions (Von Ralumer 1974).

The pre-Alpine tectonic evolution of the massif is complex. According to Bellière (1958) severa! phases of deformation are superimposed on the crystalline rocks: long isoclinal folds are deformed by post-schistosity open folds. At some stage during this complex history metabasic rocks lave been boudinaged into lenses of various sizes (from $10 \mathrm{~cm}$ to a few tens of meters wide).

Little is known about the metamorphic history prior to the pre-Alpine event (early Hercynian or older?) which has induced the regional amphibolite facies. Relics of kyanite (Bellière 1954) occurring sporadically in metapelites have led Bellière (personal communication) to surmise a polymetamorphic evolution characterized by a first phase of high pressure conditions. Another indication is provided by the present work: eclogite relics occur in the cores of the thickest metabasite boudins, where they were protected from the subsequent regional penetrative deformation. No data are available, hewever, on the time: interval which has separated these two phases of deformation.
Boudinaged amphibolites outcrop at numer. ous places in the massif. They are particularly well developed around Lac Cornu (alt. $2275 \mathrm{~m}$ ) where two important series, interleaved in gneisses, can be distinguished: group I, west of the lake, and group II, east of the lake. The latter shows a banded structure with variable composition from band to band; rocks transitional in mineral composition to the surrounding biotitic gneisses are comrnon. Group I is made up of lenses of massive structure. They have sharp contacts with the surrounding gneisses and more uniform mineral composition, except in the core of the thickest lenses, where the eclogites occur.

\section{Petrography}

Most Lac Cornu metabasites are common amphibolites and consist essentially of hornblende, plagioclase and, sometimes, garnet. They also contain sphene, biotite, quartz, apatite, oxide minerals (frequently altered to leucoxene) and sulphides as accessory minerals.

Secondary minerals produced by retrogression in late-hercynian and alpine deformations are also present in subsidiary amounts: saussurite, chlorite, clinozoisite and prehnite. These minerals locally replace the primary assemblage or fill small independent veinlets.

In group I, the cores of the thickest lenses (10 $\mathrm{m}$ or more) are made up of a garnet + clinopyroxene + hornblende + plagioclase assemblage (Fig. 1) and can be considered as eclogites in various stages of retrogression to amphibolites. Garnet (1 to $10 \mathrm{~mm}$ ), usually the most abundant mineral, is embedded in a matrix of hornblende, plagioclase (cá. $\mathrm{An}_{20}$ ), symplectitic clinopyroxene and quartz. Though grossly euhedral, it is frequently invaded by hornblende and plagioclase extending inwards from the margin of the grains. It contains numerous inclusions of all the other minerals, notably homogeneous clinopyroxene.

The matrix clinopyroxene (ca. $1 \mathrm{~mm}$ ) shows in most grains a symplectitic intergrowth with plagioclase. Two contrasted types of symplectites are observed:

(a) a coarse-grained symplectite, in which plagioclases are 20 to $30 \mu \mathrm{m}$ in size;

(b) a vermicular symplectite, extremely finegrained, which occupies parts of the clinopyroxene grains devoid of coarse-grained symplectite. 
The amount of amphibole and matrix plagioclase varies from rock to rock. It increases towards the margin of the lenses, where the rock becomes a common amphibolite, with or without garnet. The hornblende-plagioclase association always surrounds garnet, which is therefore never in sontact with the symplectite.

\section{Mineral chemistry}

Microprobe analyses were performed in the Mineralogisk-Geologisk Museum (Oslo, Norway) on an ARL-EMX instrument fitted with a LINK model 860 energy-dispersive system, using the ZAF-4 data reduction program. Extensive tests in this laboratory have shown that this system produces analyses comparable in precision and accuracy to those obtained by conventional probe andysis at the levels reported here $( \pm 2 \%$ for major elements, $\pm 5-10 \%$ for minor elements).

The analyses have been made on two samples. One sample (JPL 36) contains a smaller amount of plagioclase + hornblende than the other one (JPL 26), which is thus in a more advanced stage of amphibolitization. The bulk chemical compositions of the two rocks (see below) are very similar (anaiyses 3 and 4, Table 3), the $\mathrm{FeO}_{t} /$ $\mathrm{FeO}_{\mathrm{t}}+\mathrm{MgO}$ (mol.\%) being 0.46 and 0.40 , respectively.

Particular attention has been devoted to clinopyroxene inclusions in the garnet (Tables 1 and 2). The $\mathrm{Fe}^{3+}$ and $\mathrm{Fe}^{2+}$ contents of the clinopyroxene have been calculated from the structural formula (Essene \& Fyfe 1967; Mysen \& Griffin 1973).

Garnets are not zoned and have a composition which puts them at the transition between eclogites and amphibolites, according to Schmidt (1967). The garnet of the more amphituole-rich rock shows a more amphibolitic character.

According to the classification of Essene \& Fyfe (1967), clinopyroxene inclusions in garnet are sodic augite in the amphibole-rich rock (JPL 26) and jadeite-poor omphacite (except for grain 36-3) in JPL 36. In the latter rock, the coarsegrained symplectitic clinopyroxene contains less jadeite than some of the inclusions, but more than the pyroxene of the amphibole-rich sample. The fine-grained symplectite has not been accurately analyzed, due to the extremely fine texture. Semi-quantitative measurements indicate a jadeite content less than $15 \%$. In the classifica-
Table I. Average chemical composition of garnets.

\begin{tabular}{|c|c|c|c|c|}
\hline & \multicolumn{2}{|l|}{ Sample } & \multicolumn{2}{|l|}{ Sample } \\
\hline & JPL 36 & $\sigma$ & JPL 26 & $\sigma$ \\
\hline $\mathrm{SiO}_{2}$ & 38.64 & 0.18 & 38.35 & 0.16 \\
\hline $\mathrm{TiO}_{2}$ & $0.2 \|$ & 0.05 & 0.13 & 0.04 \\
\hline $\mathrm{Al}_{2} \mathrm{O}_{3}$ & 21.33 & 0.13 & 20.96 & 0.11 \\
\hline $\mathrm{FeO}_{\mathrm{t}}$ & 23.90 & 0.11 & 26.06 & 0.20 \\
\hline $\mathrm{MnO}$ & 0.53 & 0.07 & 0.67 & 0.07 \\
\hline MgO & 6.09 & 0.11 & 4.87 & 0.14 \\
\hline $\mathrm{CaO}$ & 9.16 & 0.10 & 9.06 & 0.25 \\
\hline $\mathrm{Na}_{2} \mathrm{O}$ & 0.12 & 0.06 & 0.24 & 0.06 \\
\hline $\mathrm{K}_{2} \mathrm{O}$ & 0.02 & 0.00 & 0.04 & 0.01 \\
\hline Total & 100.00 & & 100.38 & \\
\hline $\mathrm{Si}$ & 2.995 & & 2.996 & \\
\hline Allv & 0.005 & & 0.004 & \\
\hline $\mathbf{A l} \mathbf{l}^{\mathbf{l}}$ & 1.941 & & 1.922 & \\
\hline $\mathbf{T i}$ & 0.012 & & 0.008 & \\
\hline $\mathrm{Fe}^{3-}$ & 0.047 & & 0.070 & \\
\hline $\mathbf{F e}^{2+}$ & 1.497 & & 1.627 & \\
\hline $\mathbf{M n}$ & 0.035 & & 0.044 & \\
\hline Mg & 0.708 & & 0.571 & \\
\hline $\mathrm{Ca}$ & 0.760 & & 0.758 & \\
\hline $\mathbf{O}$ & 12.014 & & 12.022 & \\
\hline Alm & 49.9 & 0.36 & 54.2 & 0.87 \\
\hline Pyr & 23.6 & 0.44 & 19.0 & 0.53 \\
\hline Gros & 23.0 & 0.35 & 21.8 & 1.27 \\
\hline Spes & 1.2 & 0.18 & 1.5 & 0.16 \\
\hline Andr & 2.4 & 0.42 & 3.5 & 0.40 \\
\hline
\end{tabular}

$\sigma$ is the standard deviation of the mean, for 6 meisurements.

tion of Lovering \& White (1969), all slinopyroxenes lie in the eclogite field (Fig. 2).

The plagioclase from the matrix of JPL 36 $\left(A n_{20}\right)$ is richer in $\mathrm{Ca}$ than the plagioclase from the coarse-grained or the vermicular symplectites $\left(A n_{15}\right)$. The amphibole from the matrix of JPL 26 is a hornblende with a mulecular composition $\mathrm{Mg}: \mathrm{Fe}: \mathrm{Ca}$ of approximately 35:35:30.

Analyses of adjacent grains of clinopyroxenes and garnets permit salculation of equilibration temperature between the two minerals, provided an estimation of the pressure is possible (Ellis \& Green 1979). A minimum value of the pressure can be deterinined from the relation of Currie \& Curtis (1976), based upon the multicomponent theory applied to jadeitic pyroxene, provided the temperature is known and supposing that albite was in equilibrium with the clinopyroxene. Combination of the two relationships leads by itera. tion to minimum values for temperature and pressure of equilibration of the clinopyroxene 
Table 2. Chemical compositions of clinopyroxenes.

\begin{tabular}{|c|c|c|c|c|c|c|c|c|c|c|c|c|c|}
\hline & \multicolumn{6}{|c|}{ Sample JPL $\$ 6$} & \multicolumn{7}{|c|}{ Sample JPL 26} \\
\hline & $1 a$ & lb & $2 a$ & $2 b$ & 3 & 4 & 5 & $6 a$ & nh & $7 a$ & $7 \mathrm{~b}$ & 8 & 9 \\
\hline $\mathrm{SiO}_{2}$ & 52.44 & 53.25 & 53.03 & 53.23 & 52.24 & 52.79 & 50.03 & 50.83 & 52.13 & 50.96 & 51.98 & 52.61 & 51.12 \\
\hline $\mathrm{TiO}_{2}$ & 0.41 & 0.40 & 0.33 & 0.23 & 0.16 & 0.36 & 0.28 & 0.31 & 0.52 & 0.40 & 0.40 & 0.58 & 0.21 \\
\hline $\mathrm{Al}_{2} \mathrm{O}_{3}$ & 7.37 & 8.17 & 8.07 & 8.23 & 7.08 & 7.07 & 6.71 & 6.17 & 7.31 & 7.23 & 6.20 & 5.67 & 6.50 \\
\hline $\mathrm{FeO}_{\mathrm{t}}$ & 7.16 & 6.80 & 7.34 & 7.25 & 8.71 & 7.40 & 8.80 & 9.13 & 8.64 & 7.94 & 7.68 & 8.04 & $8.4 ?$ \\
\hline $\mathrm{MnO}$ & 0.00 & 0.09 & 0.08 & 0.07 & 0.16 & 0.15 & 0.00 & 0.10 & 0.16 & 0.01 & 0.08 & t. is & 0.25 \\
\hline $\mathrm{MgO}$ & 9.91 & 9.77 & 9.19 & 9.44 & 9.82 & 10.28 & 9.46 & 10.24 & 9.42 & $\mid 10.21$ & 10.84 & 11.17 & 10.00 \\
\hline $\mathrm{CaO}$ & 17.40 & 17.39 & 17.01 & 17.84 & 17.32 & 18.24 & 20.94 & 21.67 & 20.46 & 19.50 & 20.88 & 21.66 & 19.73 \\
\hline $\mathrm{Na}_{2} \mathrm{O}$ & 3.57 & 4.17 & 4.15 & 3.76 & 3.14 & 3.41 & 1.76 & 1.37 & 2.36 & 2.39 & 1.94 & 1.89 & 2.61 \\
\hline $\mathrm{K}_{2} \mathrm{O}$ & 0.09 & 0.00 & 0.05 & 0.00 & 0.05 & 0.00 & 0.78 & 0.08 & 0.03 & 0.00 & 0.09 & 0.00 & 0.00 \\
\hline Total & 98.35 & 100.04 & 99.28 & 99.94 & 99.68 & 99.70 & 98.06 & 99.91 & 101.02 & 98.64 & 100.09 & 101.27 & 98.89 \\
\hline $\mathrm{Si}$ & 1.944 & 1.932 & 1.94 .4 & 1.942 & 1.924 & 1.933 & 1.895 & 1.894 & 1.911 & 1.901 & 1.916 & 1.920 & 1.904 \\
\hline $\mathrm{Al}^{\mathrm{IV}}$ & 0.056 & 0.068 & 0.056 & 0.058 & 0.076 & 0.067 & 0.105 & 0.106 & 0.089 & 0.099 & 0.084 & 0.080 & 0.096 \\
\hline $\mathrm{Al}^{\mathrm{v}}$ & 0.265 & 0.280 & 0.293 & 0.291 & $0.23 i$ & 0.238 & 0.194 & 0.165 & 0.226 & 0.218 & 0.184 & 0.163 & 0.189 \\
\hline $\mathrm{Ti}$ & 0.011 & 0.011 & 0.010 & 0.006 & 0.004 & 0.010 & 0.008 & 0.009 & 0.014 & 0.011 & 0.011 & 0.016 & 0.006 \\
\hline $\mathrm{Fe}^{3+}$ & 0.025 & 0.059 & 0.037 & 0.019 & 0.059 & 0.051 & 0.024 & 0.023 & 0.001 & 0.031 & 0.016 & 0.019 & 0.083 \\
\hline $\mathrm{Fe}^{2}$ & 0.197 & 0.147 & 0.187 & 0.201 & 0.208 & 0.175 & 0.254 & 0.261 & 0.262 & 0.216 & 0.219 & 0.225 & 0.180 \\
\hline $\mathrm{Mn}$ & 0.000 & 0.003 & 0.002 & 0.002 & 0.005 & 0.005 & 0.000 & 0.003 & 0.005 & 0.000 & 0.002 & 0.005 & 0.008 \\
\hline $\mathrm{Mg}$ & 0.551 & 0.532 & 0.505 & 0.517 & 0.543 & 0.565 & 0.537 & 0.572 & 0.518 & 0.571 & 0.599 & 0.611 & 0.559 \\
\hline $\mathrm{Ca}$ & 0.691 & 0.676 & 0.668 & 0.697 & 0.723 & 0.716 & 0.850 & 0.865 & 0.804 & 0.779 & 0.824 & 0.827 & 0.787 \\
\hline $\mathrm{Na}$ & 0.256 & 0.293 & 0.295 & 0.266 & 0.224 & 0.242 & 0.129 & 0.099 & 0.167 & 0.173 & 0.138 & 0.133 & 0.188 \\
\hline K & 0.004 & 0.000 & 0.002 & 0.000 & 0.002 & 0.000 & 0.004 & 0.004 & 0.001 & 0.000 & 0.004 & 0.000 & 0.000 \\
\hline 0 & 5.998 & 6.000 & 5.999 & 6.000 & 5.999 & 6.000 & 5.998 & 5.998 & 5.999 & 6.000 & 5.998 & 6.000 & 6.000 \\
\hline $\mathrm{Fe}^{2+} / \mathrm{Fe}+\mathrm{Mg}$ & 0.26 & 0.22 & 0.27 & 0.28 & 0.28 & 0.24 & 0.32 & 0.31 & 0.34 & 0.27 & 0.27 & 0.27 & 0.24 \\
\hline $\mathrm{Fe}^{2+} / \mathrm{Fe}_{\mathrm{t}}$ & 0.89 & 0.71 & 0.83 & 0.91 & 0.78 & 0.77 & 0.91 & 0.92 & 0.99 & 0.88 & 0.93 & 0.92 & 0.68 \\
\hline Ti-Di & 1.1 & 1.1 & 1.0 & 0.6 & 0.4 & 0.9 & 0.8 & 0.8 & 1.4 & 1.1 & 1.1 & 11.5 & 0.6 \\
\hline Ts & 3.2 & 4.5 & 3.4 & 4.4 & 6.4 & 4.5 & 8.8 & 8.6 & 5.9 & 7.3 & 6.0 & 4.7 & 8.2 \\
\hline Jd & 22.1 & 22.7 & 24.9 & 23.8 & 15.7 & 18.3 & 10.3 & 7.4 & $\$ 6.2$ & 13.5 & 11.8 & 11.0 & 10.2 \\
\hline Ac & 2.3 & 5.7 & 3.6 & 1.9 & 5.6 & 4.9 & 2.4 & 2.2 & 0.1 & 2.9 & 1.6 & 1.8 & 8.1 \\
\hline $\mathrm{Di}+\mathrm{Hd}$ & 61.6 & 50.0 & 60.2 & 62.3 & 62.0 & 63.2 & 74.0 & 74.4 & 70.9 & 66.0 & 72.7 & 73.4 & 68.1 \\
\hline $\mathrm{E} n+\mathrm{Fs}$ & 9.7 & 6.1 & 7.0 & 7.1 & 9.9 & 8.2 & 3.8 & 9.6 & 5.5 & 9.2 & 6.8 & 7.6 & 4.8 \\
\hline $\mathrm{K}_{\mathrm{D}}$ & & 7.7 & & 5.4 & 5.5 & & 6.0 & & 5.6 & & 7.8 & & 8.9 \\
\hline $\mathbf{P}_{(\mathrm{Kb})}$ & & 1.0 & & 11.1 & 10.0 & & 4.2 & & 6.9 & & 4.0 & & 5.6 \\
\hline $\left.\mathrm{T}^{\circ}{ }^{\circ} \mathrm{C}\right)$ & & 710 & & 800 & 795 & & 740 & & 770 & & 675 & & 650 \\
\hline
\end{tabular}

1 to 3, 5 to 9: clinopyroxene inclusions in garnet.

a. b: different points in the same grain.

4: clinopyroxene in a coarse-grained symplectite.

The compositions for which valiaes of $P$ and $T$ have been calculated are from points adjacent to the enclosing garnet.

irclusions with garnet (Table 2). The minimum P,T conditions for the eclogitic assemblage of specimen JPL 36 are approximately $11 \mathrm{~Kb}$ and $780^{\circ} \mathrm{C}$ and, for specimen JPL. 26, in the range of 4 to $7 \mathrm{~Kb}$ and $650-770^{\circ} \mathrm{C}$. The high temperature is consistent with the lack of zoning in the garnet (Krogh 1977a).

\section{Metamorphic evolution}

Siructural evidence meso- and micro-scales and thermobarometric considerations indicate that the garnet-clinopyroxene association is primary and equilibrated at high pressure and temperature (nninimum $11 \mathrm{~Kb}$ and $780^{\circ} \mathrm{C}$ ). This eclogitic association later retrograded to amphibolite facies conditions.

Three mechanisms of retrogression have operated together or successively:

(1) Breakdown in two stages of the Jd-rich clinopyroxene by symplectitization. The first stage, still at relatively high pressure and temperature, yielded the coarse symplectite in which the clinopyroxene is still Jd-rich (analysis 
36, Table 2). The process however has not gone to completion. The composition of the parental pyroxene has been preserved in some parts of the grains as well as in some inciusions in the garnet. In the second stage of retrogression, the preserved part of the clinopyroxene decomposes to vermicular symplectite. It is suggested that the two stages were v/ell separated in time and P,T conditions because the two types of symplectites show no gradational relationships. The fact that the clinopyroxene inclusions are not symplectitized suggests that the breakdown process requires addition of a component (e.g. $\mathrm{SiO}_{2}$ ), the diffusion of which would have been prevented by the garnet. Oxidation of iron in the pyroxene, suggested as a possible mechanism of breakdown by Mysen \& Griffin (1973), does not seem plausible in the present case; the $\mathrm{Fe}^{3+} / \mathrm{Fe}_{1}$ ratio in the symplectitic pyroxene is not significantly different (analysis 4, Table 2) from that in the Jd-rich pyroxene of the inclusion. Similar textural relationships and variety in clinopyroxene conposition are common in eclogites (e.g. Mysen 1972).

(2) Breakdown of garnet through the classical reaction garnet + Jd-clinopyroxene $+\mathrm{H}_{2} \mathrm{O} \rightarrow$ plagioclase + horriblende, or one of its variants (see Mysen \& Heier 1972). The reaction accounts for the fact that garnet never occurs in contact with the matrix clinopyroxene. Preservation of clinopyroxene as inclusions in garnet suggests that diffusion of water through the garnet was the mechanism controlling the reaction.

(3) Amphibolitization of the symplectitic clinopyroxene, which implies the opening of the system to constituents other than water during the reaction.

The difference between minimum $\mathrm{P}, \mathrm{T}$ conditions calculated for rocks JPL 36 and JPL 26 may on:y mean that different compositions of plagioclase were last in equilibrium with the jadeitic pyroxene. Indeed a lower ontent of albite in the assumed coexisting plagioclase would give a higher P value by Currie \& Curtis's barometer, which in turn would lead to somewhat higher temperatures with Ellis $\mathcal{E}$ Green's thermometer. Bulk chemical analyses (analyses 3 and 4 in Table 3) cannot be used to reconstitute the composition of the plagioclase originally present in the assemblage because, as demonstrated below, the $\mathrm{Na}$ and $\mathrm{Ca}$ contents of the rocks have not remained constant during the evolution. It

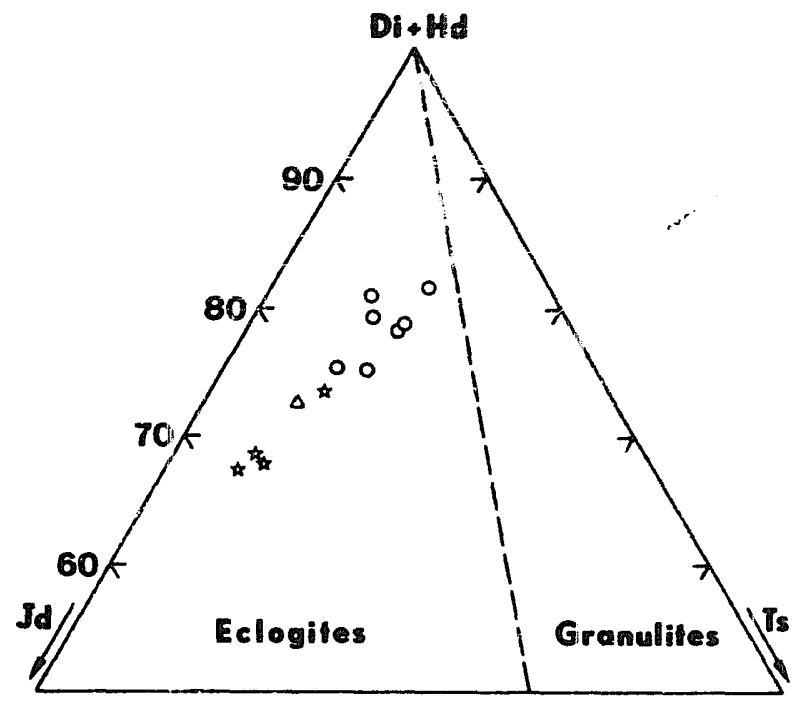

Fig. 2. Clinofyroxene cumpositions plotted in the $\mathrm{Jd}-\mathrm{Di}+\mathrm{Hd}-$ Ts triangle of Lovering \& White (1969). is sample JPL 36; $\triangle$ in a coarse-grained symplectite (sample JPL 36); $O$ sample JPL 26.

will alsc be shown below that, although JPL 26 and JPL 36 were originally not very different in composition, the former was slightly more basic than the latter. JPL 26 could thus have contained a plagioclase with a lower content in albite than JPL 36.

An alternative explanation would invoke the influence of retrogression. Lower $P, T$ conditions indeed characterize we more amphibolitized sample (JPL 26). Locally clinopyroxene inclusions are rimmed by minute amounts of plagioclase (Fig. 1) and/or hornblende. It is thus possible that the inclusions have lost some jadeite in a similar way to coarse symplectitization or have re-equilibrated with the garnet through the reaction seen above, during part of the $P, T$ retrogression. The dispersion of the measured $\mathbf{P}$ and $T$ indicates that the processes could have reached different stages of completion from inclusion to inclusion.

It should also be roted that the $\mathrm{Fe} / \mathrm{Mg}+\mathrm{Fe}$ ratios of both garnet and clinopyroxene are higher in rock JPL 26 than in rock JPL 36 (Table's 1 and 2), although the bulk chemical compositions of the rocks indicate an inverse relations hip (Table 3). It is suggested that the clinopyroxene and garnet compositions shift towards higher $\mathrm{Fe} / \mathrm{Mg}$ ratio during retrogression because they would equilibrate with a hornblende of relatively lower $\mathrm{Fe} / \mathrm{Mg}$ ratio. Absence of zoning in the garnet would indicate that the reaction took 
Table 3. Major and minor element compositions of rock samples.

\begin{tabular}{|c|c|c|c|c|c|c|c|c|c|c|c|c|}
\hline \multirow[b]{2}{*}{$\%$} & \multicolumn{12}{|c|}{ Group I } \\
\hline & 1 & 2 & 3 & 4 & 5 & 6 & 7 & 8 & 9 & 10 & 11 & 12 \\
\hline $\mathrm{SiO}_{2}$ & 46.93 & 50.05 & 49.68 & 50.43 & 48.53 & 48.07 & 47.70 & 51.55 & 50.67 & 47.70 & 49.94 & 50.17 \\
\hline $\mathrm{TiO}_{2}$ & 1.03 & 1.13 & 1.16 & 1.51 & 1.66 & 1.82 & 2.06 & 1.92 & 2.24 & 2.32 & 2.32 & 2.49 \\
\hline $\mathrm{Al}_{2} \mathrm{O}_{3}$ & 16.30 & 15.70 & 15.62 & 14.40 & 13.68 & 13.86 & 13.44 & 14.04 & 13.43 & 13.27 & 12.94 & 13.21 \\
\hline $\mathrm{Fe}_{2} \mathrm{O}_{3} \mathrm{t}$ & 11.94 & 11.79 & 11.65 & 13.17 & 14.15 & 16.00 & 15.59 & 15.04 & 15.99 & 16.27 & 16.00 & 15.07 \\
\hline $\mathrm{MnO}$ & 0.19 & 0.21 & 0.21 & 0.22 & 0.21 & 0.28 & 0.26 & 0.25 & 0.24 & 0.24 & 0.25 & 0.24 \\
\hline $\mathrm{MgO}$ & 8.63 & 8.31 & 8.65 & 7.68 & 8.10 & 6.60 & 7.68 & 5.65 & 6.47 & 6.94 & 6.88 & 5.63 \\
\hline $\mathrm{CaO}$ & 9.47 & 10.11 & 9.71 & 10.02 & 10.06 & 10.36 & 9.70 & 8.76 & 8.59 & 0.17 & 8.91 & 9.96 \\
\hline $\mathrm{Na}_{2} \mathrm{O}$ & 3.30 & 2.92 & 3.34 & 2.78 & 2.96 & $2.3 \vdots$ & 2.24 & 2.09 & 2.41 & 2.20 & 1.27 & 3.21 \\
\hline $\mathrm{K}_{2} \mathrm{O}$ & 0.61 & 0.49 & 0.96 & 0.21 & 0.40 & 0.07 & 0.47 & 0.30 & 0.28 & 0.31 & 0.41 & 0.07 \\
\hline $\mathrm{P}_{2} \mathrm{O}_{5}$ & 0.10 & 0.12 & 0.12 & 0.12 & 0.16 & 0.27 & 0.14 & 0.18 & 0.18 & 0.25 & 0.27 & 0.05 \\
\hline Total & 98.50 & 100.84 & 101.10 & 100.54 & 100.07 & 100.29 & 99.28 & 100.79 & 100.50 & 99.67 & 101.22 & 100.32 \\
\hline \multicolumn{13}{|l|}{ (ppm) } \\
\hline V & 306 & 310 & 315 & 366 & 377 & 383 & 458 & 435 & 453 & 479 & 447 & 457 \\
\hline $\mathrm{Ni}$ & 81 & 65 & 74 & 47 & 63 & 61 & 43 & 36 & 50 & 46 & 44 & 41 \\
\hline $\mathrm{Cr}$ & 273 & 242 & 274 & 164 & 261 & 279 & 68 & 54 & 79 & 85 & 62 & 58 \\
\hline Co & 40 & 42 & 32 & 34 & 34 & 41 & 31 & 36 & 38 & 32 & 43 & 26 \\
\hline $\mathbf{R b}$ & 18 & 18 & 33 & 8 & 11 & 12 & 15 & 7 & 3 & 12 & 12 & 5 \\
\hline $\mathrm{Sr}$ & 115 & 123 & 184 & 189 & 91 & 87 & 125 & 98 & 100 & 99 & 78 & 116 \\
\hline $\mathrm{Zr}$ & 42 & 44 & 53 & 85 & 90 & 101 & 117 & 123 & 136 & 144 & 165 & 176 \\
\hline$Y$ & 24 & 26 & 25 & 35 & 38 & 38 & 49 & 47 & 47 & 51 & 54 & 50 \\
\hline
\end{tabular}

Group I

I: JPL 46: Eclogitic amphibolite

2: JPL 45: Eclogitic amphibolite

3: JPL 26: Eclogitic amphibolite

4: JPL 36: Eclogitic amphibolite

5: E 24: Eclogitic amphibolite

6: E 23: Amphibole-bearing eclogite

place at still high temperatures. Metasomatic mobility of $\mathrm{Ca}$ (see below) and oxidation of $\mathrm{Fe}$ increase the complexity of the system.

\section{Chemical variations in metabasites}

Major and minor elements were analyzed by $X-1:$ ty fluorescence on a CGR-ALPHA 2020 semi-autornatic spectrometer. Norrish \& Hutton's (1969) method was used for major elements which were determined on ignited samples. Trace elements were measured on pressed pellets. Matrix corrections were calculated for $\mathrm{Zr}$, $\mathrm{Y}, \mathrm{Rb}$ and $\mathrm{Sr}$ on the basis of the major elernent contents using standard values for the absorption coefficient, and for $\mathrm{V}, \mathrm{Ni}, \mathrm{Co}$ and $\mathrm{Cr}$ on the basis of the background intensities. International rocks standards, inchuding USGS specimens, were used for the calibration. Precision, estimated from replicate determinations, is better than $\pm 2 \%$ for $\mathrm{Z}, \mathrm{r}, \mathrm{Sr}, \mathrm{V}$, and $\mathrm{Rb}$ contents higher
7: JPL 28: Garnet-bearing amphibolite
8: JPL 6: Eclogitic amphibolite
9: JPL 39: Eclogitic amphibolite
10: JPL 33: Eclogitic amphibolite
11: E 21: Garnet-bearing amphibolite
12: JPL 27: Amphibole-bearing eclogite

than $10 \mathrm{pprn}, \pm 5 \%$ for $\mathrm{Ni}, \mathrm{Cr}, \mathrm{Co}$, and $\mathrm{Y}$ contents higher than 20 ppm.

The analyses of twelve metabasites of group I and five of group II as well as five gneisses transitional from group II amphibolites to the surrounding gneisses are reported in Table 3.

The magmatic affinities of the metabasites are obvious when applying the criteria of Leake (1964), Shaw (1972), Matthes et al. (:975) and Moine \& de La Roche (1968) (Fig. 3).

Moreover, the analyses of group I show smooth trends when plotted in the $\mathrm{Al}_{2} \mathrm{O}_{3}-\mathrm{FeO}$ $+\mathrm{Fe}_{2} \mathrm{O}_{3}-\mathrm{MgO}$ diagram of Besson \& Font eilles (1974), (Fig. 4). The usefulness of this diagram for the study of metamorphic basic rocks has been demonstrated by Fonteilles (1976) and Demange \& Frignet (1977). Al, Fe, Mg are considered to be immobile elements in alteration processes, and therefore any original igneous trend should be preserved when plotted relative to these elements. Moreover this diagram easily discriminates between the tholeiitic and calc-alkaline series (Besson \&: Fonteilles 1974). 


\begin{tabular}{|c|c|c|c|c|c|c|c|c|c|}
\hline \multicolumn{5}{|c|}{ Group II } & \multicolumn{5}{|c|}{ Surrounding, gneisses } \\
\hline a & $\mathbf{b}$ & c & d & e & I & II & III & IV & v \\
\hline 51.76 & 48.75 & 45.60 & 48.66 & 50.06 & 55.98 & 59.68 & 67.74 & 64.69 & 11.42 \\
\hline 0.52 & 0.74 & 3.77 & 2.04 & 0.36 & 0.80 & 0.93 & 0.79 & 0.75 & 0.35 \\
\hline 19.18 & 17.39 & 16.14 & 19.14 & 17.43 & 18.18 & 16.70 & 15.24 & 15.76 & 14.75 \\
\hline 8.02 & 9.57 & 12.71 & 10.44 & 7.73 & 7.74 & 7.07 & 6.70 & 7.04 & 3.97 \\
\hline 0.14 & 0.16 & 0.24 & 0.16 & 0.14 & 0.11 & 0.13 & 0.05 & 0.10 & 0.07 \\
\hline 7.78 & 9.03 & 9.03 & 7.71 & 9.33 & 5.27 & 3.83 & 2.52 & 3.79 & 0.67 \\
\hline 8.71 & 10.80 & 9.98 & 8.95 & 11.00 & 5.56 & 5.76 & 1.48 & 1.94 & 2.32 \\
\hline 3.44 & 2.35 & 1.80 & $3.3 i$ & 2.06 & 2.64 & 3.24 & 1.96 & 2.89 & 3.40 \\
\hline 0.98 & 0.71 & 0.67 & 0.66 & 1.61 & 1.54 & 1.69 & 2.66 & 2.40 & 2.86 \\
\hline$<0.1$ & $<0.1$ & $<0.1$ & $<0.1$ & 0.11 & 0.21 & 0.18 & 0.11 & $<0.1$ & 0.10 \\
\hline 100.53 & 99.51 & 99.93 & 101.06 & 99.83 & 98.04 & 99.20 & 99.29 & 99.36 & 99.91 \\
\hline 221 & 195 & 501 & 335 & 194 & 202 & 145 & 167 & 134 & 37 \\
\hline 21 & 65 & 22 & 26 & 56 & 52 & 33 & 57 & 96 & 8 \\
\hline 178 & 426 & 143 & 386 & 386 & 138 & 75 & 149 & 212 & $<10$ \\
\hline 32 & 32 & 34 & 37 & 33 & 12 & 19 & 20 & 19 & $<10$ \\
\hline 50 & 24 & 31 & 32 & 87 & $6 ?$ & 64 & 110 & 92 & 79 \\
\hline 264 & 203 & 109 & 234 & 258 & 45? & 458 & 192 & 222 & 322 \\
\hline$<5$ & $<5$ & 10 & $<5$ & $<5$ & 157 & 154 & 200 & 177 & 290 \\
\hline 6 & 6 & 8 & i & 6 & 3 & 27 & 27 & 23 & 38 \\
\hline
\end{tabular}

Group II

a: JPL 15: Amphibolite

b: JPL 16: Biotite-bearing banded amphibolite c: JPL 18: Biotite and oxide-bearing amphibolite d: JPL 19: Garnet-clinopyroxene amphibolite e: JPL 47: Amphibolite

Two Skaergaard trends are also plotted in Fig. 4 , following the reconstruction of Wager (Wager \& Brown 196i8) and also the recent re-evaluation by Brooks \& Nielsen (1978), on the basis of thick dykes related to the main intrusion. It is striking that group I defines a trend parallel to Wager's and almost identical to Brook's. Group I rocks can therefore be considered as a succession of magmatic residual liquids formed by low-pressure fractional crystallization. The most $\mathrm{Mg}$-rich liquid of group I plots not far from Brook's parental magma for the Skaergaard and could thus represent a similar magma at a slightly more evolved stage.

The magmatic trend in group I rocks can also be demonstrated with other elements. In Fig. 5 each element is plotted against $\mathrm{Zr}$, which is an immobile (Fioyd \& Winchester 1975), and magmatophile element (Treuil \& Joron 1975; Allègre \& Minster 1978). Its content in basaltic suites always increases in successive liquids produced by fractional crystallization. Indeed, when $\alpha$ is the fraction of liquid rernaining trap-
Surrounding gneisse:

I: JPL 42: Garnet-bearing biotitic gneiss (adjacent to an amphibolite lens)

II: JPL 41: Hornblende, biotite gneiss

III: JPI. 8: Biotitic gneiss

IV: JPI. 35: Garnet gneiss

V: JPL 43 Migmatitic hornblende and biotite-bearing gneiss

ped into a cumulate made by the fractionating assemblage of minerals, the Rayleigh law indicates that the concentration of a magmatophile element in the liquid varies proportionaliy to

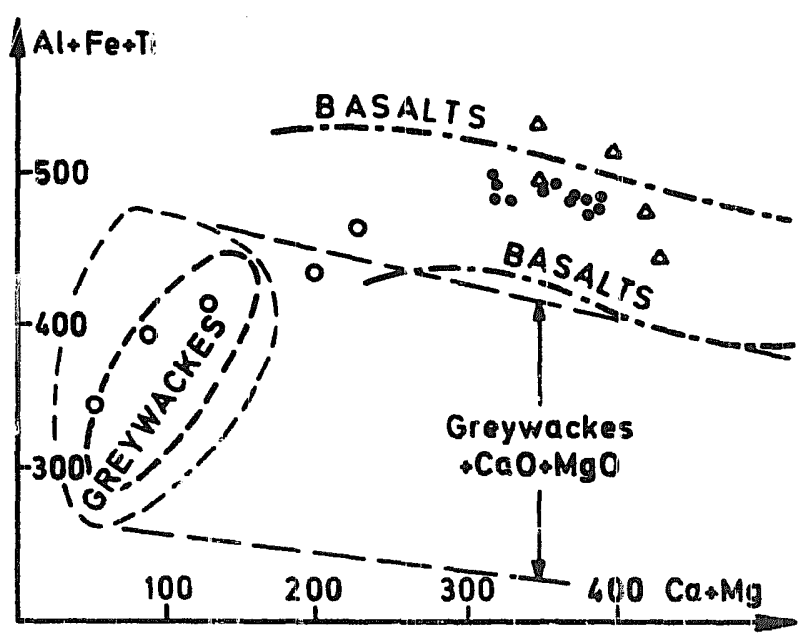

Fig. 3. Representation in Moine \& de La Roche's diagram (1968) of metabasic rocks of group I (이), group II ( $\angle$ ) and the surrounding gneisses $(O)$. Al, re ... etc., are the contents in milliatoms of each element in $100 \mathrm{~g}$ of rock. 


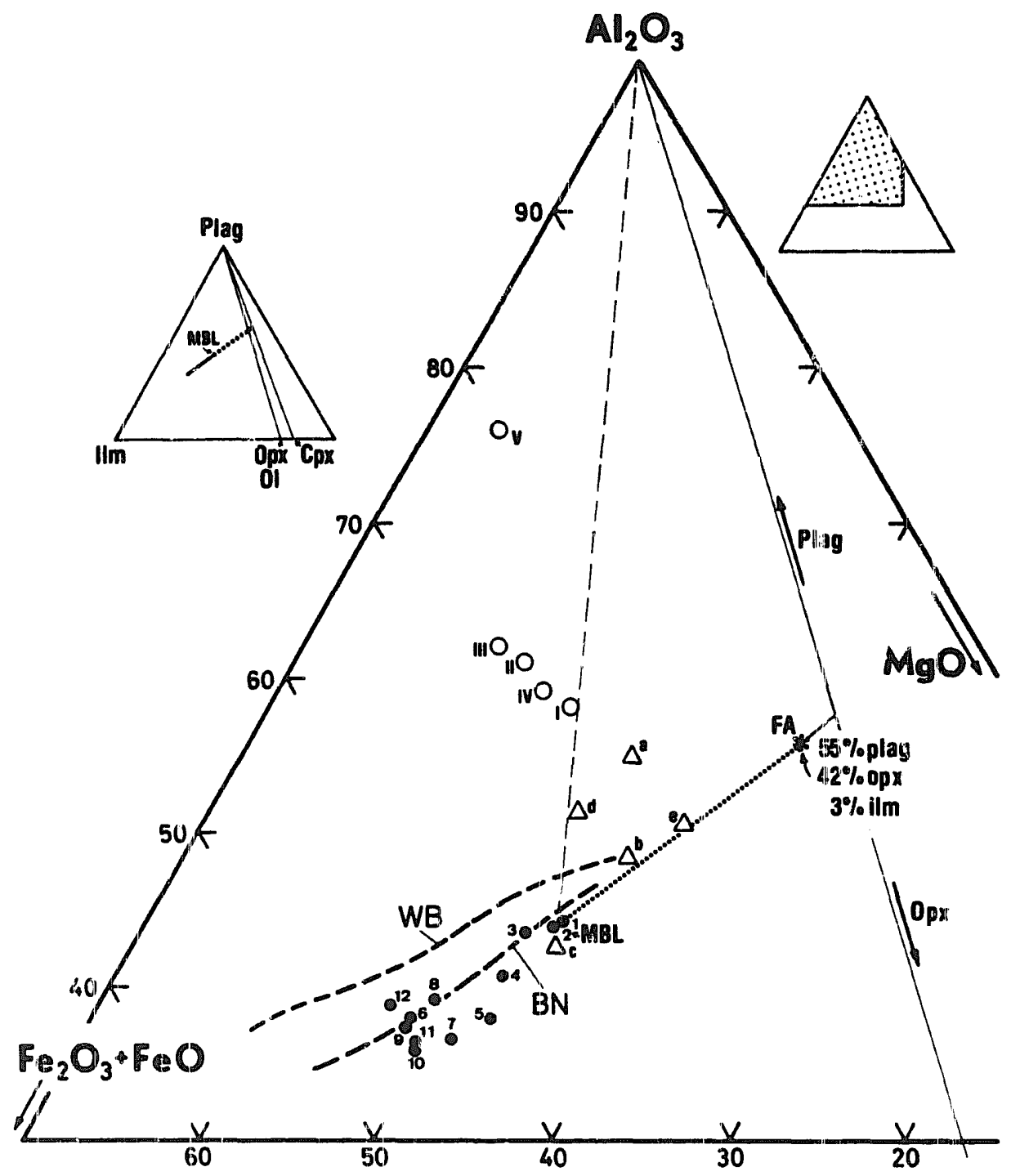

Fig. 4. $\mathrm{Al}_{2} \mathrm{O}_{: 3}-\mathrm{Fe}_{2} \mathrm{O}_{3}+\mathrm{FeO}-\mathrm{MgO}$ diagram showing the evolution of group I metabasic rocks (O), parallel to the Skaergaard trends of Wager \& Brown (1968) (W/B) and of Brooks \& Nielsen (1978) (BN). Group II metabasites ( $\triangle$ ) and surrounding gneisses (O) are also plctted. The fractionating assemblage (FA) which can be subtracted from the most basic liquid (MBL) to produce the group i trend, is also represented. Numbers and letters refer to analyses in Table 3. Inset shows the different minerals which can coexist with the most basic liquid (MBL) as well as the graphic construction giving the approximate plagioclase content.

$\mathrm{F}^{x-1}, \mathrm{~F}$ being the fraction of residual liquid (Greenland 1970). When $\alpha$ is zero, the variation is inversely proportional to $F$ (Anderson \& Greendand 1969).

Fig. 5 clearly displays well defined trends not only for $\mathrm{Al}, \mathrm{Fe}$ and $\mathrm{Mg}$ but also for Ti, Y, Mn, $\mathrm{P}$, $\mathrm{Ni}, \mathrm{Cr}$, Co and $\mathrm{V}$.

We regard this as good evidence that all these elements were irnmobille or nearly so during the entire history of the rock. It is therefore permissible to determine the nature and proportions of the minerais which fractionated at the beginning of the rnagmatic evolution.

\section{Modelling the fractionating assemblage}

Assuming a $\mathrm{Fe}_{2} \mathrm{O}_{3}$ content of $1.50 \%$, following the now classical view of Coombs (1963), the $\mathrm{FeO} / \mathrm{MgC}$ ratio of the most basic liquid $(\mathrm{MBL}=$ average of rocks 1 and 2 ) can be calculated. The $\mathrm{FeO} / \mathrm{MgO}$ ratios of a possible olivine (ol) and/or an orthopyroxene (opx) which would crystallize in equilibrium with such a liquid, are calculated from Roeder \& Einslie's (1970) distribution coefficient $K=0.30$, using similar values of $K$ for ol and opx (Ito 1972; Duchesne 
Fig. 5. Diagram showing the variation of each element against ZZr. Sample numbers are the same as in Table 3. The dotted bands define the trends compatible with a fractional crystallization model. The dashed line indicaties trends not compratible with a fractional crystallization model.
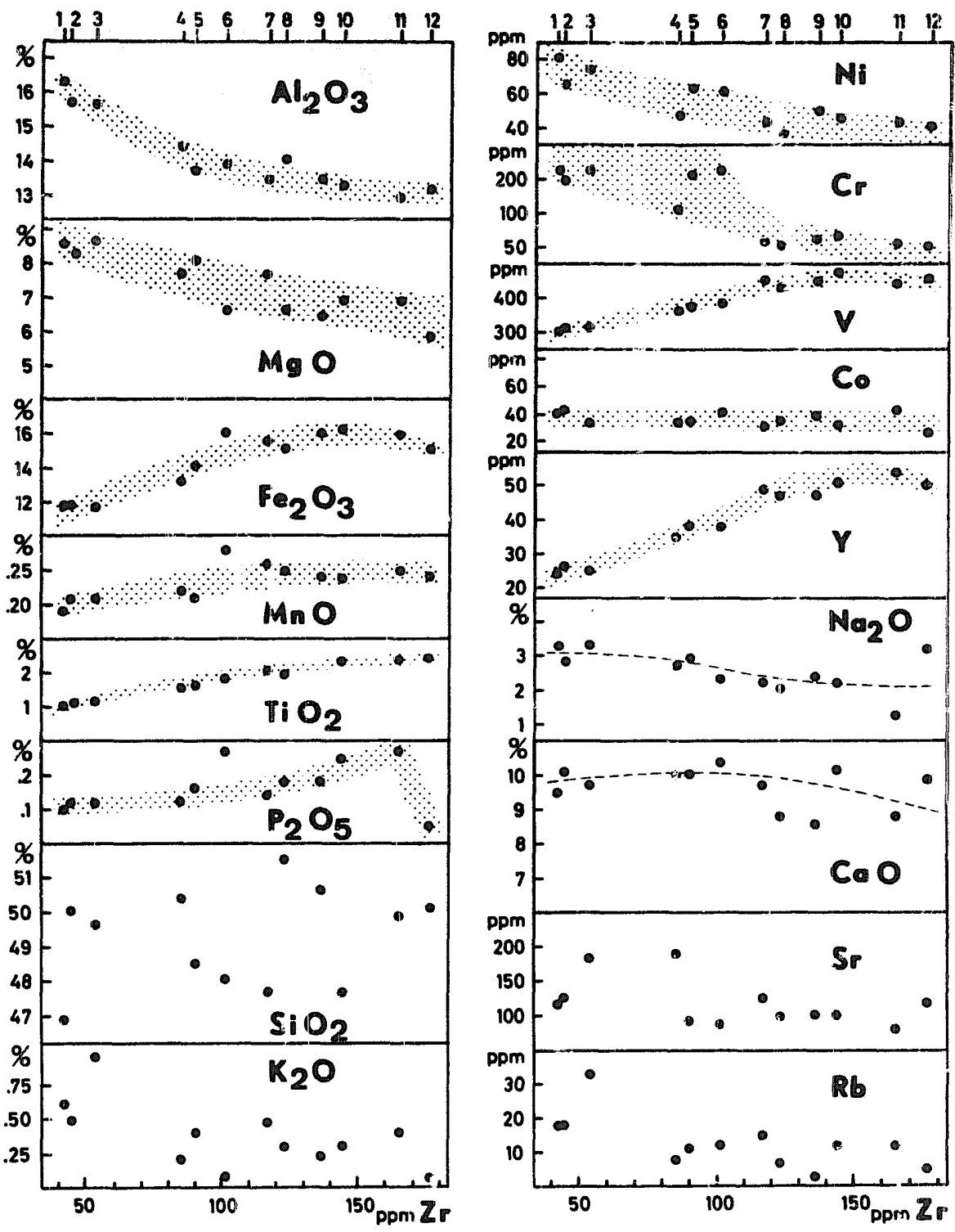

1972b). The distribution coefficient of $\mathrm{FeO} / \mathrm{MgO}$ between opx and clinopyroxene (cpx) is about 0.73 (Kretz 1961) in igneous rocks. Therefore, the mafic assemblage that could crystallize from MBL is $\mathrm{Fo}_{85}, \mathrm{En}_{85}$ and a cpx with $\mathrm{MgO} /$ $\mathrm{MgO}+\mathrm{FeO}=0.89$.

A simple graphic construction (Fig. 4, inset) gives the proportions of piagioclase (plag) in the assemblage when cpx is the only mafic present (59 wt.\%) and when ol and/or. opx crystallize without cpx (57\%).

A better estimation of the proportions of ol, opx and cpx cannot be obtained with major elements since $\mathrm{SiO}_{2}$ and $\mathrm{CaO}$ are not considered immobile. Trace elements can however be used in a semi-quantitative approach to answer that question.
In bilogarithmic diagrams (Fig. 6) in which the content of an element $(\mathrm{Cr}, \mathrm{V}, \mathrm{Ni}$ and $\mathrm{Ti})$ is plotted against $\mathrm{Zr}$, the evolution can be roughly approximated by straight lines (or succession of straight lines - Duchesne 1978) the slopes of which are equal to $\bar{D}-1 / \bar{D}_{\mathrm{zr}}-1, \bar{D}$ and $\bar{D}_{\mathrm{zr}}$ being the bulk partition coefficients of the element and $\mathrm{Zr}$, respectively. Since $\mathrm{Zr}$ is magmatophile, $\bar{D}_{\mathrm{zr}}$ is negligible relative to 1 and the slope becomes $1-\bar{D}$, where $\bar{D}=\Sigma \mu_{j} D_{j}$ wi $\bar{i}_{\text {: }}$ $\mu_{j}$ the weight fraction of mineral $j$ in the fractionating assemblage and $D_{j}$ the distribution coefficient of the element between mineral $j$ and the liquid.

At the beginning of the crystallization, the slopes of the straight line evolutions indicate $\bar{D}$ values not far from 1. This precludes crystalliza- 


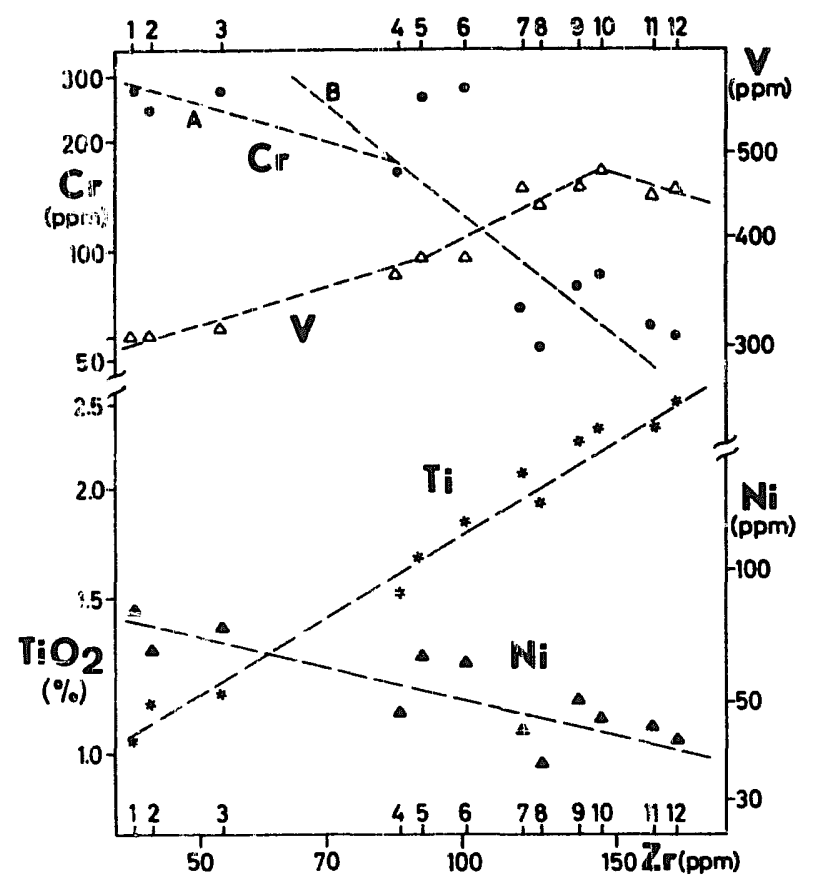

Fig. 6. Diagram in logarithmic coordinates showirg the variation of $\mathrm{Cr}, \mathrm{V}, \mathrm{Ti}$ and $\mathrm{Ni}$ against $\mathrm{Zr}$. The straight line or the succession of straight lines are the calculated models (see text). Tv:o different models are proposed for the beginning of the evolution of $\mathrm{Cr}$ : model $\mathrm{A}$ ignores rocks 5 and 6 ; an average trend is assumed in model $\mathrm{B}$.

tion of significant amounts of olivine and clinopyrox $\leqslant$ se because these minerals strongly fractionate $\mathrm{Ni}$ and $\mathrm{Cr}$ respectively, $D_{\mathrm{Ni}}^{\mathrm{ol}}=13$; $D_{i}^{c p x}=20$ (Bougault 1977 ) and would thus considerably increase the $\bar{D}$ values.

It can be calculated that the mineral assemblage $55 \%$ plagioclase $+42 \%$ orthopyroxene + $3 \%$ (hemo)ilmenite, with the $D_{j}$ values reported in Table 4, gives the graphic solution represented in Fig. 6. This fractionating assemblage is plotted in Fig. 4.

The agreement between the calculated model and the measured values is good for $\mathrm{Ti}, \mathrm{V}$ and $\mathrm{Ni}$ as well as for the low values of $\mathrm{Cr}$. However, for $\mathrm{Cr}$, iwo rocks (Table 3, analyses 5 and 6) fall outside a reasonable deviation from the calculated curve. Unless one is prepared to accept that these rocks could be exceptions, it is possible to suggest another "alverage' morel (model B, Fig. 6) which implies a constant decrease during the evolution. Even in this extreme case, assuming the values of $D$ reported in Table 4 , a relatively small amount of $\mathrm{cpx}(6 \%)$ can explain the evolution without significant change for the other elements.

The absence of ol and cpx or, at least, the low
Tahle 4. Mineral/liquid distribution coefficients.

\begin{tabular}{llcccc}
\hline & & $\mathrm{Ti}$ & $\mathrm{Cr}$ & $\mathrm{Ni}$ & $\mathrm{V}$ \\
\hline \multirow{2}{*}{ Orthopyroxene } & (a) & 0.2 & 3.0 & 3.5 & 0.25 \\
& (b) & 0.14 & 2.9 & 6.7 & 0.10 \\
IImenite & (a) & 10 & 20 & 4 & 20 \\
& (b) & 10 & 40 & 13 & 8 \\
Clinopyroxene & (a) & 0.2 & 20 & 3.5 & 0.25 \\
& (b) & 0.2 & 20 & 4.0 & 0.20 \\
\hline
\end{tabular}

(a) This work; (b) from Steinberg et al. (1979).

content of cpx in the fractionating assemblage is plausible. A noritic stage is indeed present in layered intrusions of tholeiitic affinities e.g. Stillwater (Wager \& Brown 1968) and BjerkremSogndal (Duchesne 1972b), the latter being also characterized by occurrence of hemoilmenite at the same stage (Duchesne 1972a). Cpx and/or magnetite may have appeared later in the Lac Cornu evolution as suggested by changes in slopes in the $\mathrm{V}$ and $\mathrm{Cr}$ trends (Fig. 6).

The $D_{j}$ values adopted here for the opx are in good agreement with those of Steinberg et ai. (1979) (Table 4). Different values are however preferred here for $\mathrm{Cr}, \mathrm{Ni}$ and $\mathrm{V}$ in (hemo)ilmenite. They are justified by the fact that these authors have acopted the same distribution coefficients for ilmenite and magnetite, in contradiction with data obtained for pairs of magnetite and ilmenite (Duchesne 1972a), which indicate a strong enrichment of $\mathrm{Ni}$ and $\mathrm{Cr}$ in magnetite relative to ilmenite, and of $\mathrm{V}$ in hemoilmenite relative to pure ilmenite.

Thus the beginning of the evolution of major and minor immobile elements can be described by a quantitative model of fractional crystallization in which the degree of internal consistency is quite satisfactory. This constitutes good evidence that the Lac Cornu metabasites of group I are of igneous origin. Moreover, since the fractionating assemblage is typical of low-P conditions, it can be concluded that the chemical variations were acquired in crustal conditions.

\section{Metabasites of group II}

Rocks of group III (analyses (a) to (e), Table 3) plot outside the trend of group I in Fig. 4 and thus need a different interpretation.

Several surrounding gneisses have been 
analyzed (Table 3 ) in order to establish their relationships with group II rocks. Moine \& de La Roche's diagram (Fig. 3) grossly shows that the gneisses were originally greywackes or transitional between greywackes and more basic material. The complete discussion of the geohemistry of these rocks falls outside the scope of the present paper. Nevertheless, on the basis of the present data, a simple mixing process between the gneisses and group I rocks cannot account for the chemical characters of group II rocks. Indeed Fig. 4 shows that points $a, b$ and $e$ fall outside the possible mixing area between points 1 to 12 and I to V. Fig. 3 even indicates an opposite trend. Moreover, the low $\mathrm{Zr}$ content of group II rocks is particularly difficult to explain, the sedimentary component being richer than group I metabasites (Table 3).

A magmatic interpretation could be supported by inert major elements (Fig. 4). The rocks could be variously interpreted as plagioclase-tholeiites (PL-tholeiites of Shido et al. 1971) (rocks $a$ and d) or liquids similar o the MBL of group I enriched either in plagioclase phenocrysts (rock $d)$ or in the fractionating assemblage plagioclase + orthopyroxene (rocks $b$ and $e$ ). This interpretation, however, does not account for the trace element constraints: $\mathrm{Zr}$ and $\mathrm{Y}$ are very depleted in group II, Ni is too low in rocks $a$ and $d$ for a liquid more basic than MBL or for a plagioclaseenriched rock.

Unless one accepts the existence of a magmatic component of unusual composition, a compiex control of the trace element evolution and/or a strong metasomatic alteration, it is difficult to build a plausible geochemical model for group II rocks on the basis of the available data. Nevertheless the overall magmatic affinities and the transitional character towards meta-greywackes are geochemical and field evidence that would suggest the group II to be made of metatuffites of volcano-sedimentary origin.

\section{Mobility and metasomatism}

Regularity in the chemical evolution, similarity $v$ ith a known magmatic trend and consistency with a fractional crystallization model, are the cliteria used here to decide that $\mathrm{Al}, \mathrm{Mg}, \mathrm{Fe}, \mathrm{Ti}$, $\mathrm{Cr}, \mathrm{V}, \mathrm{Ni}$ and $\mathrm{Zr}$ were inert during the entire post-magmatic evolution of the rocks. Though not discussed in detail $\mathrm{P}, \mathrm{Y}, \mathrm{Co}$ and $\mathrm{Mn}$ also follow regular trends compatible with fractional crystallization and can thus be classed with inert elements. On the other hand, $\mathrm{Si}$ and $\mathrm{K}$ and to a lesser extent $\mathrm{Rb}$ and $\mathrm{Sr}$, display a great deal of scattering and are therefore considered mobile. $\mathrm{Na}_{2} \mathrm{O}$ decreases and $\mathrm{CaO}$ remains generally constant with decreasing $\mathrm{MgO}$, two tendencies that are different from the Skaergaard model, in which $\mathrm{Na}$ increases and $\mathrm{Ca}$ decreases with decreasing $\mathrm{MgO}$. $\mathrm{Na}$ and $\mathrm{Ca}$ are therefore also considered mobile.

Though the rocks are not on the average significantly different from a tholeiitic basalt (Coffrant \& Piboule 1975), the original chemical composition of individual samples has suffered metasomatic changes during their evolution. Bard \& Moine (1979) have shown that in a thick. metabasite series, down to the amphibolite/ ganulite facies transition, the metasomatic alteration due to metamorphism of medium to high grade intensity is minor, even for $\mathrm{K}_{2} \mathrm{O}$. Here, variations due to metamorphism or to any prior e:vent cannot be discriminated. The high grade conditions of eclogitization and subsequent retrogression imply outward and inward movements of a fluid phase, the composition of which can have changed greatly with time at the contact with the neightoring rocks. In this connection, the relatively small thickness of the metabasites can have greatly favored mietasomatism by reducing the necessary distance of m gration between rocks of different compositions. Another possible cause of chem cal alteration might be some sedimentary reworking of tuffaceous material, as the complex chemical composition of group II metabasites seems to indicate.

\section{Continental origin and geochemical criteria}

Field evidente indicates that on the scale of the Aiguilles Rouges massif the quantities of metabasites are volumetrically insignificant relative to the metamorphosed stdimentary rocks. Group I metabasites could thus originally represent dykes or sills, intruded into a sedimentary series in a contintental domain or at its margin and subsequently metamorphosed and transposed in the regional foliation. Occurrence of differentiated dykes of similar composition related to the Si isergaard intrusion (Brooks \& Nielsen 1978) strongly supports this hypothesis. 
Group II metabasires could have a volcanosedimentary origin.

This interpretation precludes an oceanic origin for the tholeiites. It is interesting to note that application of geochemical discrimination criteria lead to different conclusions. The Pearce \& Cann (1973) discrimination diagran using the immobile elements $\mathrm{Zr}, \mathrm{Ti}$ and $\mathrm{Y}$, indicates that the most basic liquic (MBL) of group I rocks is a low-K tholeiite and the successive liquids, ocean-floor basalis. The discrimination functions of Piboule (1977), which take into account the major elements except $\mathrm{K}_{2} \mathrm{O}$ which is considered to be the most mobile major element, also lead to inconsistert results: the MBL, would be an ocean-floor basalt or a marginal-basin tholeiite, the rest of the trend from rock 4 would be continental tholeiites. Piboule's functions thus appear to be too sensitive to metasomatic variations., even to small ones, and, as already noted by Piboule himself, are inappropriate to differentiation series.

A further inconsistency in the u'se of trace element discrimination functions apiears when the $\mathrm{Sr}-\mathrm{Ti}-\mathrm{Zr}$ diagram of Pearce \& Cann (1973) is applied to the Skaergaard related dyk 6 :s analyzed by Brooks \& Nielsen (1978). The series starts as low-K tholeiite, and extends across the oceanfloor basalt field in complete discrepancy with the geological occurrence.

Even greater care must, therefore, be exercised when applying geochemical criteria based upon empirical or statistical relationships to metamorphosed basic rocks, since these could have suffered metasomatic alterations.

\section{Conclusions}

Group I metabasites are made of eclogitic amphibolites in various stages of retrogression to amphibolites. Application of Ellis \& Green (1974) and Currie \& Curtis (1976) relationships to garnet and clinopyroxene inclusions in garnet leads to minimum PT equilibrium conditions, for the least retrograded sampie, of around $780^{\circ} \mathrm{C}$ and $11 \mathrm{~Kb}$. This corresponds to deep crustal conditions for the eclogitization in a relatively low geothermal gradient $\left(15^{\circ}-20^{\circ} / \mathrm{Km} \mathrm{r}\right)$.

Retrugression to amphibolite facies conditions happened in two stages. The amount of available water was the factor controlling amphibolitization.

The Aiguilles Rouges massif has thus gone through a phase of high pressure conditions during its pre-Alpine history, before being metamorphosed into the amphibolite facies. This constitutes further evidence of a polymetamorphic regional evolution.

Immobile major and trace elements of eclogitic amphibolites can be identified by the fact that they behave in close conformity with magmatic trends. On the other hand, elements which do not show any trend or do not conform to a possible magmatic trend, can be considered mobile. The high grade of metamorphism and later retrogression are possible, but not necessarily unique, causes of metasomatic mobility.

Group I metabasites display a typical low-P fractionation trend, namely the Skaergaard trend. Moreover, it can be shown through quantitative modelling that a plagioclase-bearing assemblage fractionates at the beginning of the evolution. This leaves little doubt as to a crustal evolution of the original material and its in situ metamorphism. The method suggested in this paper provides a supplementary criterion to distinguish between the autochthonous and foreign nature of the eclogites (Krogh 1977; Lappin 1977; Lappin \& Smith 1978).

Group II metabasites fail to conform with a simple geochemicall model, but occurrence of rocks trarsitional to the surrounding grieisses, as well as the overall banded character of the rocks, favor a volcano-sedimentary origin.

The small size of the individual metabasite lenses, their limited volume relative to the other gneisses and the abundance of metasedimentary rocks in the regional series, indicate a continental environment for the basic rocks. Paradoxically application of common trace and major element criteria leads to an oceanic origin. It should however be mentioned that the Skaergaard rocks would also be considered oceanic, with the same criteria. These criteria must therefore be refined.

No geodynamic information can be obtained from the tholeiitic nature of the magma, since this type of magmatism is not characteristic of any narticular environment (Pearce \& Cann 1973; Girod 1978).

Acknowledgements. - W. L. Griffin has generously contrituted to the present work by carrying out the microprobe analyses at the Mineralogisk-Geologisk Museum (Oslo, Norway). J. Bellière has supervised the field work. Both are warmly thanked for numerous discussions throughout the study. The final version of the paper has benefited from their criticisms. The 'Collectif interuniversitaire de Gécchimie in- 
strumentale' (University of Liège) provided logistical support. G. Bologne kindly helped with the analyses. JPL received a grant from the Paul Fourmarier Foundation.

\section{References}

Allegre, C. J. \& Minste!", J. F. 1978: Quantitative models of trace element behavior in magmatic processes. Earth Planet. Sci. Lett. 38, 1-25.

Anderson, A. T. \& Greenland, L. P. 1969: Phosphorus fractionation diagram as a quantitative indicator of crystallization differentiation of basultic liquids. Geochim. Cosmochim. Acta 33, 493-505.

Bard, J. P. \& Moine, B. 1979; Acebuches amphibolites in the Aracena hercyniain metamorphic belt (southwest Spain): geochemical variations and basaltic affinities. Lithos 12 , 271-282.

Belliere, J. 1954: Sur la présence des silicates d'alumine (sillimanite, andalousite, disthène) dan s le massif des Aiguilles Rouges (Haute Savoie). C.R. Arad. Sci. Paris 239. 1395-1397.

Belliere, J. 1958: Contribution à l'étude pétrogénétique des schistes cristallins du massif des Aiguilles Rouges (Haute Savoie). Ann. Soc. Géol. Belg. 81, 1-198.

Belliert, J. 1980a: Le massif des Aiguilles Rouges. 26th Intern. Geol. Congress, Paris, Guide-Book to excursion 149c.

Belliere, J. (edit.) 1980b: Carte géologique de France au 1:50000e Feuille Chamonix ( $n^{\prime \prime} 608$ ), Bł $\mathrm{K} M$.

Belliere, J. \& Streel, M. 1980: Roches d'ầ-e viséen supérieur dans le massif des Aiguilles Rouges (F te Savoie). C.R. Acad. Sci. Paris, in press.

Besson, M. \& Fonteilles, M. 1974: Relations entre les comportements contrastés de l'alumine et du fer dans la différentiation des séries tholéitique et calco-alcaline. Bull. Soc. Fr. Minér. Cristall. 97, 445-44\%.

Bougault, H. 1977: Evidence de la cristallisation fractionée au niveau d'une ride médio-océanique: $\mathrm{Co}, \mathrm{Ni}, \mathrm{Cr}$, FAMOUS, leg37 du DSDP. Bull. Soc. Géol. France 19, 1207-1212.

Brooks, C. K. \& Nielsen. T. F. D. 1978: Early stages in the differentiation of the Skaergaard magma as revealed by a closely related suite of dike rocks. Lithos $I I, 1-14$.

Bryhni, 1., Krogh, E. \& Griffin, W. L. 1977: Crustal derivation of Norwegian eclogites: a review. Neues Jahrb. Miner. Abh. $130,49-68$.

Coffrant, D. \& Piboule, M. 1975: Les métavulcanites basiques du Bas Limousin (Massif Central français). Etude géochimique des éclogites et des dolérites. Bull. Soc. Géol. France 17, 620-628.

Coombs, D. S. 1963: Trends and affinities of basaltic magmas and pyroxenes as illustrated on the diopside-olivine-silica diagram. Mineral. Soc. Am., Spec. Pap. 1, 227-250.

Currie, K. L. \& Curtis, L. W. 1976: An application of multicomponent solution theory to jadeitic pyroxenes. $J$. Geol. 84, 179-195.

Demange, M. \& Frignet, B. 1977: Les roches basiques de l'Ayrole (commune de Fraisse-sur-Agout, Hérault), massif de l'Agout, Montagne Noire. Etude chimique. Bull. Soc. Fr. Minéral. Cristallogr. 100, 114-122.

Duchesne, J. C. 1972a: Iron-titanium oxide minerals in the Bjerkrem-Sogndal massif, Southwesiern Norway. J. Petrol. 13, 57-81

Juchesne, J. C. 1972b: Pyroxenes et olivines dans le massif de Bjerkrem.Sogndal (Norvège méridionale). Contribution à l'étude de la série anorthosite-mangérite. 24th Inter. Geol. Congr., Miontreal sect. 2, 320-328.
Duchesne, J. C. 1978: Quantitative modeling of $\mathrm{Sr}, \mathrm{Ca}, \mathrm{Rb}$ and $\mathbf{K}$ in the Bjerkrem-Sogndal layered lopolith (S.W.Norway). Conirib. Mineral. Pctrol. 66, 175-184.

Ellis, D. J. \& Green, D. H. 1979: An experinental study of the effect of $\mathrm{Ca}$ upon garnet-linopyroxene $\mathrm{Fe}-\mathrm{Mg}$ exchange equilibria. Contrib. Mineral. Petrol. 7I, 13-22.

Essene, E. J. \& Fyfe, W. S. 1967: Ompiacite in Californian metamorphic rocks. Contrib. Mineral. Petrol. 15, 1-23.

Floyd, P. A. \& Winchester, J. A. 1975: Magma type and tectonic setting discrimination using immobile elements. Earth Planet. Sci. Lett. 27, 211-218.

Fonteilles, M. 1976: Essai d'interprétation des compositions chimiques des ioches d'origines métamorphiques et mazmatiques du massif hercynien de l'Agly (Pyrenées orientales). Thèse. Université de Paris VI, 685 p.

Girod, M. 1978: Séries volcaniques et tectonique des plaques. In 'Les roches volcaniques; pétrologie et cadre structura!'. M. Girod (ed.), Doin, Paris, 239 p.

Greenland, L. P. 1970: An equation for trace element distribution during magmatic crystallization. Am. Mineral. 55, 455465.

Ito, K. 1973: Anclytical approach to estimating the source rock of hasaltic magmas: major elements. J. Geophys. Res. 78, $412-431$.

Kretz, R. 1961: Some applications of thermodynamics to coexisting minerals of variable composition. I. Geol. 69, 36I-387.

Krogh, E. J. 1977a: Evidence of a Precambrian continent-continent collision in Western Norway. Nature 267, 17-19.

Krogh, E. J. 1977b: Crustal and in situ origin of Norwegian eclogites. Nature 269, 730.

Lappin, M. A. 1977: Crustal and in situ origin of Norwegian eclogites. Nature 269, 730, 1977.

Lappin, M. A. \& Smith, D. C. 1978: Mantle-tquilibrated orthopyroxene eclogite pods from the Basal gneisses in the Selje District, Western Norway. J. Petı.J. 19, 530-584.

Leake, B. E. 1964: The chemical distinction between orthoand para-amphibolites. J. Petrol. 5. 238-254.

Lovering, J. F. \& White, A. J. R. 1969: Granulitic and eclogitic inclusions from basic pipes at Delegate. Australia. Contrib. Mineral. Petrol. 21, 9-52.

Matthes, S., Richter, P. \& Schmidt, K. 1975: Die Eklogitvorkommen des kristallinen Grundgebirges in NE-Hayern. IX. Petrographie, Geochemie und Petrogentese des Liklogite des Munchberger Gneissgebietes. Neues Jahrb. Miner. Abh. 126, 45-86.

Moine, B. \& de La Roche, H. 1968: Nouvelle approche du problème de l'origine des amphibolites à partir de leur composition chimique. C.R. Acad. Si i. Paris 267D. 2084 2087.

Mysen, B. \& Heier, K. S. 1972: Petrogenesis of eclogites in high grade metamorphic gneisses, exemplified by the Hareidland eclogite, Western Norway. Contrib. Mineral. Petrol. 36, 73-94.

Mysen, B. 1972: Five clinopyroxenes in the Hareidland eclogite, Western Norway. Contrib. Mineral. Petrol. 34. 31.5325.

Mysen, B. \& Griffin, W. L. 1973: Pyroxene stoichiometry and the breakdown of omphacite. Am. Mineral. 58, 60-63.

Norrish, K. \& Hutton, J. T. 1969: An accurate X-ray spectrographic method for the analysis of a wide range of geological samples. Geochim. Cosmochim. Acta 33, 431453.

Pearce, J. A. \& Cann, J. K. "973: Tectonic setting of basic volcanic rocks determined using trace element analyses. Earth Planet. Sci. Lett. 19, 290-300.

Piboule, M. 1977: Utilisation de l'analyse factorielle dis- 
críminarte pour la reconnaissance de la nature des magmas parents des amphibolites. Application à quelques métabasites du Rouergue at du Limousin (Massif Central Français). Bull. Soc. géol. France 19, 1133-1143.

Roeder, P. L. \& Emslie, R. F. 1970: Olivine-liquid equilibrium. Contrib. Mineral. Petrol. 29, 275-289.

Schmidr, K. 1967: Die Eklogitvorkommen des kristallinen Grundgebirges in NE Bayern. I. Der Granat der Eklogite, Eklogitamplhibolite und Granatamphibolite des Münchberger Gneissgebietes. Neues Jahrb. Miner. Abh. 107, 74-112.

Shaw, D. M. 1972: The origin of the Apsley gneiss, Ontario. Can. J. Earth Sci. 9, 18-35.

Shido, F., Miyashiro, A. \& Ewing, M. 1971: Crystallization of abyssal tholeiites. Contrib. Mineral. Petrol. 31, 251-266.

Steinberg, M., Treuil, M. \& Touray, J. C. 1979: Geochimie (principes et méthodes): II. Cristallgchimie at p̈lérnents en traces. Doin, Paris. 599 pp.

Treuil, M. \& Joron, J. L. 1975: Utilisation des éléments hygromagmatophiles pour la simplification de: la modélisation quantitative des processus magmatiques. $\mathbb{E x e m p l e s}$ de "'Afar et la clorsale médioatlantique. Soc. Ital. Mineral. e Petrol., Milano 3I, 125-174.

Von Raumer, J. F. 1974: Zur Metamorphose amphibolitischer Gesteine im Altkristallin des Mont-Blanc- und AiguillesRouges-Massivs. Schweiz. Mineral. und Petrogr. Mitt. j4, 471-487.

Wager, L. R. \& Brown, G. M. 1968: Layered Igneous Rocks, Oliver \& Boyd Ltd, London. 588 pp.

Accepted for publication July 1980

Inrinted January 1981 